\title{
DETERMINATION OF THE COMPRESSION INDEX OF RECONSTITUTED CLAYS USING INTRINSIC CONCEPT AND NORMALIZED VOID RATIO
}

\author{
*Farzad Habibbeygi ${ }^{1}$, Hamid Nikraz ${ }^{2}$ and Fred Verheyde ${ }^{3}$ \\ ${ }^{1,2}$ Faculty of Science and Engineering, Curtin University, Australia; ${ }^{3}$ Douglas Partners, Australia \\ *Corresponding Author, Received: 8 May 2017, Revised: 23 May 2017, Accepted: 22 June 2017
}

\begin{abstract}
Measurement of the compression indexes of clayey soils, particularly reconstituted clays with a high initial water content, is generally time-consuming and costly. A mitigation of these constraints could include a correlation between the compression indexes and the consistency limits of the clay soil that can be measured reliably. In this paper, the time-tested concepts of intrinsic framework and normalisation methods were used to derive a correlation between the compression indexes of reconstituted clays and the soil void ratios at consistency limits. The proposed method is based on the assumption that a unique relationship exists between consolidation pressures and consistency limits. Furthermore, the equation was simplified to estimate the compression index as a function of consistency indexes. Then, the equation was validated via comparison with a wide range of results reported in the literature regarding various types of clay. Results of this comparison suggest that there is an exclusive relationship between compression index and consistency limits for reconstituted clays.
\end{abstract}

Keywords: Compression index, reconstituted clay, liquid limit, plastic limit, clay

\section{INTRODUCTION}

The compression characteristic of soils, is a critical parameter in geotechnical engineering for the prediction of the settlement of structures, in particular if the foundation material is a clayey soil [1-3]. The rate of consolidation of a clayey layer can be identified by its compressibility, which is often expressed in terms of void ratio and effective vertical stress [4]. The slope of the linear portion of a compression curve, which is usually referred to as 'Virgin Compression Line' (VCL), is often used to represent the compressibility behaviour of a soil (Fig. 1) [4].

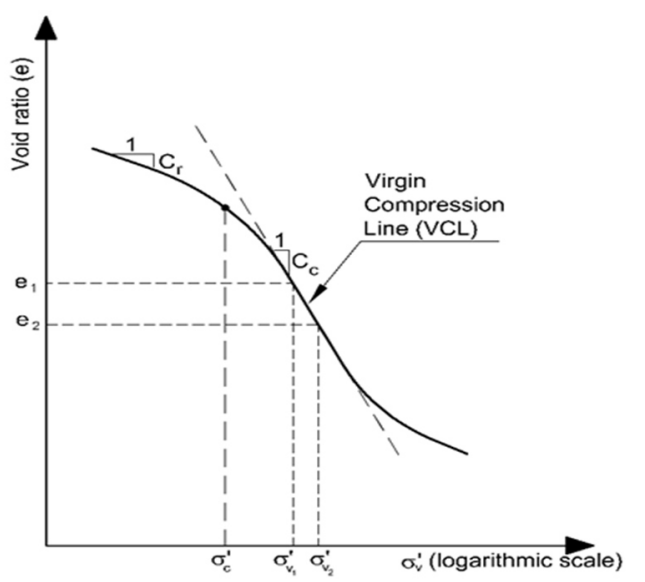

Fig. 1 Schematic plot of a compression curve in e$\log \sigma_{v}^{\prime}$ space (Redrawn from [4]).
The total settlement $(\Delta \mathrm{H})$ of a structure constructed on a clay layer can be estimated from the following relation [4]:

$\Delta H=\frac{\Delta e H}{1+e_{0}}$

where $H$ is the thickness of the clay layer, and $e_{0}$ is the void ratio at an initial effective stress of $\sigma_{0}^{\prime}$. The decrease in void ratio $(\Delta e)$ can be determined from the following equations, depending on the degree of preconsolidation of the clay layer [4].

For a normally consolidated clay:

$\Delta e=C_{c} \log \frac{\sigma_{0}^{\prime}+\Delta \sigma}{\sigma_{0}^{\prime}}$

For an over-consolidated clay:

if $\sigma_{0}^{\prime}+\Delta \sigma<\sigma_{c}^{\prime}, \Delta e=C_{r} \log \frac{\sigma_{0}^{\prime}+\Delta \sigma}{\sigma_{0}^{\prime}}$

if $\sigma_{0}^{\prime}<\sigma_{c}^{\prime}<\sigma_{0}^{\prime}+\Delta \sigma$,

$\Delta e=C_{r} \log \frac{\sigma_{c}^{\prime}}{\sigma_{0}^{\prime}}+C_{c} \log \frac{\sigma_{0}^{\prime}+\Delta \sigma}{\sigma_{c}^{\prime}}$

where $H$ is the thickness of the clay layer, $e_{0}$ is the void ratio at an initial effective vertical stress of $\sigma_{0}^{\prime}, \Delta \sigma$ is the increment of stress applied to the clay layer, $\sigma_{c}^{\prime}$ is the preconsolidation stress of the clay layer, $C_{c}$ is the virgin compression slope (compression index), and $C_{r}$ is the recompression slope (recompression index). For a normally consolidated clay, the only parameter needed to compute $\Delta e$ is $C_{c}$, which is the slope of the virgin 
compression line (i.e. the straight part of the compression curve) $[2,4]$. However, for an overconsolidated soil, there are two more parameters required to compute total settlement, namely, recompression index $\left(C_{r}\right)$, and preconsolidation stress $\left(\sigma_{c}^{\prime}\right)$.

Compressibility can be conventionally determined by laboratory or field tests [1-4]. However, such tests are cumbersome and expensive. They are particularly difficult for reconstituted samples such as marine clays that have been prepared at a water content greater than their liquid limit $[5,6]$. Therefore, it may be useful to estimate the compression index by simply measuring soil classification parameters such as liquid limit, plastic limit, natural water content, in situ void ratio, or porosity [7]. These parameters can also be measured reasonably accurately in most traditional geotechnical laboratories without the requirement for sophisticated testing. In the past six to seven decades, many researchers have proposed empirical relationships for a broad range of soil types and sample conditions to predict soil compressibility using the previously-mentioned geotechnical parameters [1-3, 7-20]. To name a few, a summary of some of these relationships is provided in Table 1.

Table 1 Some equations used to estimate the compression index of clays

\begin{tabular}{|c|c|}
\hline Equations & Reference \\
\hline$C_{c}=0.007\left(w_{L}-7\right)$ & {$[1]$} \\
\hline$C_{c}=0.007\left(w_{L}-10\right)$ & {$[2]$} \\
\hline \multicolumn{2}{|l|}{ Remolded clays } \\
\hline \multicolumn{2}{|l|}{$C_{c}=0.009\left(w_{L}-10\right)$} \\
\hline \multicolumn{2}{|l|}{ Undisturbed clays } \\
\hline$C_{c}=0.29\left(e_{0}-0.27\right)$ & {$[3]$} \\
\hline$C_{c}=0.43\left(e_{0}-0.25\right)$ & {$[7]$} \\
\hline$C_{c}=0.02+0.014 I_{P}$ & {$[8]$} \\
\hline$C_{c}=0.01\left(w_{0}-5\right)$ & {$[9]$} \\
\hline$C_{c}=0.5 I_{P} G_{s}$ & {$[10]$} \\
\hline$C_{c}=0.015\left(w_{L}-19\right)$ & {$[11]$} \\
\hline$C_{c}=0.01\left(w_{0}-7.55\right)$ & {$[12]$} \\
\hline$C_{c}=0.2237 e_{L}$ & {$[13]$} \\
\hline
\end{tabular}

$$
\begin{aligned}
& C_{c}=0.2343 e_{L} \\
& C_{c}=0.274 e_{L} \\
& C_{c}=0.156 e_{0}+0.0107 \\
& C_{c}=0.007\left(I_{s}+18\right) \\
& C_{c}=0.0103 w_{0} \\
& C_{c}=0.015 I_{P}-0.0198 \\
& C_{c}=\frac{n_{0}}{371.747-4.275 n_{0}}
\end{aligned}
$$

Note: $\boldsymbol{C}_{\boldsymbol{c}}$, compression index; $\boldsymbol{w}_{\boldsymbol{L}}$, liquid limit; $\boldsymbol{e}_{\mathbf{0}}$, initial or in situ void ratio; $\boldsymbol{I}_{\boldsymbol{P}}$, plasticity index; $\boldsymbol{w}_{\mathbf{0}}$, initial or insitu water content; $\boldsymbol{G}_{\boldsymbol{s}}$, specific gravity; $\boldsymbol{e}_{\boldsymbol{L}}$, void ratio at liquid limit; $\boldsymbol{I}_{\boldsymbol{s}}$, shrink limit; $\boldsymbol{n}_{\mathbf{0}}$, insitu porosity.

Most empirical relations are supposed to estimate a soil compression index under a wide range of conditions. However, representing a unique equation to reliably estimate the compression index $\left(C_{c}\right)$ for all types of soil classifications and soil states is almost impractical due to the complexity of soil structures, mineralogy, and inevitable sample disturbance. Thus, any suggested equation must be used carefully and be suited to the relevant soil conditions. In fact, the assessment of the compression index $\left(C_{c}\right)$ for a clayey soil (which is determined by laboratory oedometer tests) is highly influenced by the soil state. Another parameter that affects the compression behaviour of clays is the sampling procedure. Sampling disturbance has an especially great impact on sensitive clays with compression curves that are no longer linear. It is now well established that compression curves for reconstituted clays are non-linear [21, 22]. However, there are several different relationships used to link compression index to consistency limits, and only a few have been developed especially for high level of moisture content. To the authors' knowledge, there is also a lack of experimental data for predicting the compression index of a soil with high initial water content. In the present paper, a new equation for estimating the compression index of reconstituted clays is proposed, using the intrinsic and normalisation concepts. First, a regression normalisation line is proposed based on the results of one-dimensional consolidation tests on four studies that were performed on reconstituted clays. Then an empirical equation is derived by using the equation of normalisation line as well as the theoretical criterion for shear strength at consistency limits proposed by Wroth and Wood, 1978 [10]. Finally, the derived equation is 
validated using a broader range of data available from the literature regarding clayey soils with different mineralogy, soil conditions and soil classifications to evaluate the applicability of the equation to other clays.

\section{NORMALIZING COMPRESSION CURVES OF RECONSTITUTED CLAYS}

The concept of using void ratio at the liquid limit to normalise compression results was originally proposed by Nagaraj and Murthy, 1983, $1986[13,23]$. In this study, nineteen series of compression data from seven different reconstituted clays were used to plot normalised compression curves (graph of normalised void ratio versus effective vertical stress) within the stress range of $50-2000 \mathrm{kPa}$. Geotechnical parameters, such as consistency limits and specific gravity values from the consolidation database, are tabulated in Table 2. Liquid and plastic limits $\left(w_{L}\right.$, $w_{P}$ ) of the studied soils ranged from $42 \%$ to $200 \%$ and $23 \%$ to $108 \%$, respectively; plasticity indexes $\left(I_{P}\right)$ varied broadly, from 16 to 94 ; specific gravity $\left(G_{s}\right)$ ranged from 2.60 to 2.83 . Compression curves of the investigated soils are presented in Fig.2 (a) in the form of void ratio versus effective vertical stress in a semi-logarithmic plane. Consolidation data is also normalised in Fig.2 (b) using normalised void ratio $\left(e / e_{L}\right)$. As illustrated in Fig.2 (b), for consolidation stresses greater than 50 $\mathrm{kPa}$, compression curves are confined within a narrow band of $e / e_{L}$ against vertical consolidation stress $\left(\sigma_{v}^{\prime}\right)$ in a semi-log plane. Moreover, the equation of the narrow band can be fitted with a straight line with an acceptable correlation coefficient $\left(R^{2}=0.96\right)$ as follows:

$e / e_{L}=1.3402-0.3162 \log \sigma_{v}^{\prime}$

where $e$ is the void ratio, $e_{L}$ is the void ratio at the liquid limit, and $\sigma_{v}^{\prime}$ is the effective vertical stress in $\mathrm{kPa}$.

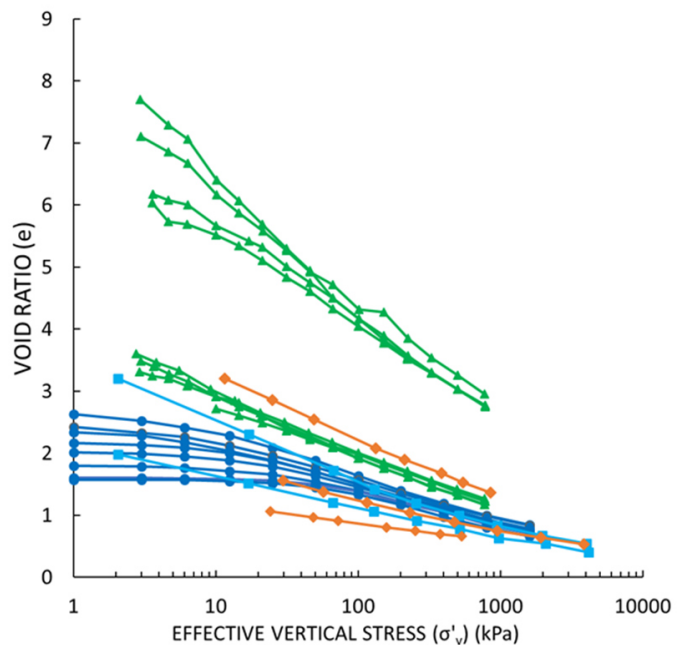

(a)

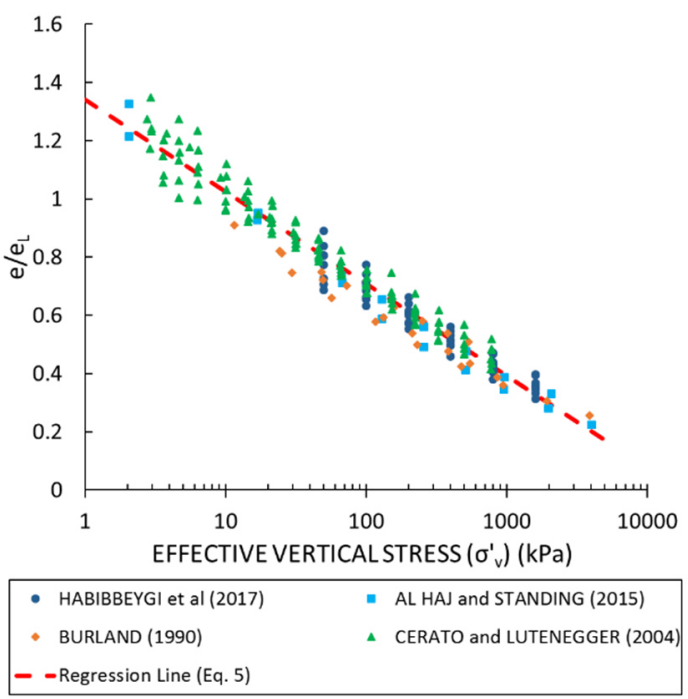

(b)

Fig. 2 Compression curves in semi-logarithmic space, data extracted from references [22, 24-27]

(a) $e-\log \sigma_{v}^{\prime}$ space

(b) Normalised compression curves in $e / e_{L^{-}}$ $\log \sigma_{v}^{\prime}$ space

Table 2 Geotechnical parameters of the studied soils

\begin{tabular}{lccccc}
\hline Soil Description & $\begin{array}{c}\boldsymbol{w}_{\boldsymbol{L}} \\
(\mathbf{\%})\end{array}$ & $\begin{array}{c}\boldsymbol{W}_{\boldsymbol{P}} \\
\mathbf{( \% )}\end{array}$ & $\begin{array}{c}\boldsymbol{I}_{\boldsymbol{P}} \\
(\mathbf{\%})\end{array}$ & $\boldsymbol{G}_{\boldsymbol{s}}$ & Reference \\
\hline Kleinbelt Ton & 127 & 36 & 91 & 2.77 & {$[24]$} \\
London clay & 67 & 27 & 40 & 2.71 & {$[24]$} \\
Wiener Tegel & 47 & 22 & 25 & 2.76 & {$[24]$} \\
Black soil & 60 & 30 & 30 & 2.72 & {$[25]$} \\
Red soil & 87 & 33 & 54 & 2.78 & {$[25]$} \\
Kaolinite & 42 & 26 & 16 & 2.68 & {$[26]$} \\
Boston Blue clay & 45 & 23 & 22 & 2.80 & {$[26]$} \\
Atchafalaya & 101 & 35 & 66 & 2.80 & {$[26]$} \\
Attapulgite & 202 & 108 & 94 & 2.83 & {$[26]$} \\
Baldivis clay & 82 & 35 & 47 & 2.60 & {$[22]$} \\
\hline
\end{tabular}


The compression curves of the reconstituted clays presented in Fig.2(b), are replotted in Fig. 3 using the intrinsic framework. The 'intrinsic concept' was first termed by Burland, 1990 [24] for correlating the inherent compression curves of reconstituted clays and was widely used afterwards by other researchers to present the compression behaviour of clays. Burland, 1990 [24] introduced an 'Intrinsic Compression Line' (ICL), which is derived by plotting the void index $\left(I_{v}\right)$ against vertical stress in a semi-log plane to study the compression behaviour of reconstituted clays. The void index $\left(I_{v}\right)$ used in the intrinsic concept is defined as follows:

$I_{v}=\frac{e-e_{100}^{*}}{e_{100}^{*}-e_{1000}^{*}}$

where the values of $e_{100}^{*}$ and $e_{1000}^{*}$ are the void ratios of the vertical stresses at $100 \mathrm{kPa}$ and 1000 $\mathrm{kPa}$, respectively. Burland, 1990 [24] also proposed a polynomial equation to express the unique intrinsic compression line (ICL) in terms of effective vertical consolidation stress at a range of liquid limits varying widely between 25 and $128 \%$ : where $\sigma_{v}^{\prime}$ is the effective vertical stress

$I_{v}=2.45-1.285\left(\log \sigma_{v}^{\prime}\right)+0.015\left(\log \sigma_{v}^{\prime}\right)^{3}$

expressed in $\mathrm{KPa}$. The equation for the ICL (Equation 7) can be used for a range of stresses between 10 and $4000 \mathrm{kPa}$.

The ICL can normalise the virgin compression curves of a clayey soil reasonably well for medium to high levels of vertical consolidation stress [22]. Although there is an impact of initial water content on the compression behaviour of reconstituted clays at low stress levels [21, 22], both methods of normalisation, i.e. void index and normalised void ratio at the liquid limit, plot the compressibility of reconstituted clays in a narrow band as vertical consolidation stress increases (greater than 50 $\mathrm{kPa}$ ). The relation of the void index (Fig. 3) can be expressed by a linear regression, with a correlation coefficient of 0.98 , of the form:

$I_{v}=2.142-1.055\left(\log \sigma_{v}^{\prime}\right)$

As seen on Fig. 3, in the range of studied stresses, a good agreement exists between the ICL proposed by Burland, 1990 [24], Eq. 7, and the regression line proposed in this study (Eq. 8). Although there is a slight disparity at stress levels higher than $2000 \mathrm{kPa}$, the proposed equation almost coincides with Burland's results for stresses between $50-2000 \mathrm{kPa}$. Similarly, Horpibulsuk et al, 2016 [27] proposed that virgin compression curves using an intrinsic framework are nearly unique for stresses higher than $100 \mathrm{kPa}$. However, this boundary stress can be reduced to $50 \mathrm{kPa}$ for clayey soils with high initial water content to reflect a wider range of stress. In fact, the aforementioned linear regression equations can be used to express the compressibility of reconstituted clays above the A-line of plasticity chart, which is the soil type considered in this study.

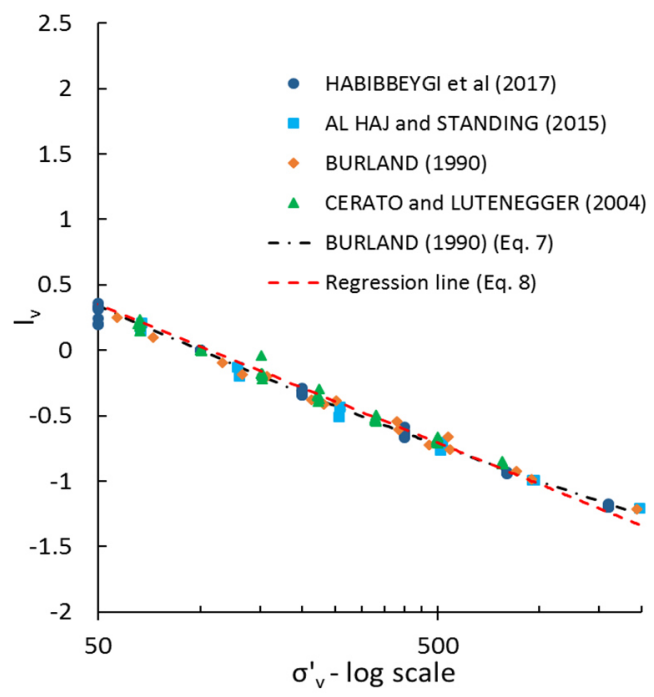

Fig. 3 Normalised compression curves in $I_{v}$ - $\log \sigma_{v}^{\prime}$ space

\section{DETERMINING COMPRESSION INDEX}

Skempton and Bishop, 1954 [28] showed that a relationship exists between the shear strength of clayey soils and their liquid limit. Moreover, it is now well-established that the shear strength of all clayey soils at water contents near the liquid limit is consistently $1.7 \mathrm{kPa}[10,29-31]$. Wroth and Wood, 1978 [10] also reported that the major principal effective vertical stress in a normally consolidated soil is almost constant for all types of fine grained soils and is equal to $6.3 \mathrm{kPa}$ at the liquid limit. Furthermore, according to Wroth and Wood, 1978 [10], the shear strength of a clayey soil at its plastic limit is approximately $100-150$ times the correlated shear strength at its liquid limit. Therefore, it can be presumed that the stress at the plastic limit of a clayey soil would be 100 150 fold greater than the related vertical stress at its liquid limit $(6.3 \mathrm{kPa})$, i.e. approximately 800 $\mathrm{kPa}$. This assumption will be verified later in this paper by testing the reliability of the estimated compression index values by comparing them with measured values. The compression index $\left(C_{c}\right)$, by definition, is the slope of the compression curves in a semi-log plane (Fig. 4): 
$C_{c}=-\frac{\Delta e}{\Delta \log \sigma_{v}^{\prime}}=\frac{e_{1}-e_{2}}{\log \sigma_{v_{2}}^{\prime}-\log \sigma_{v_{1}}^{\prime}}$

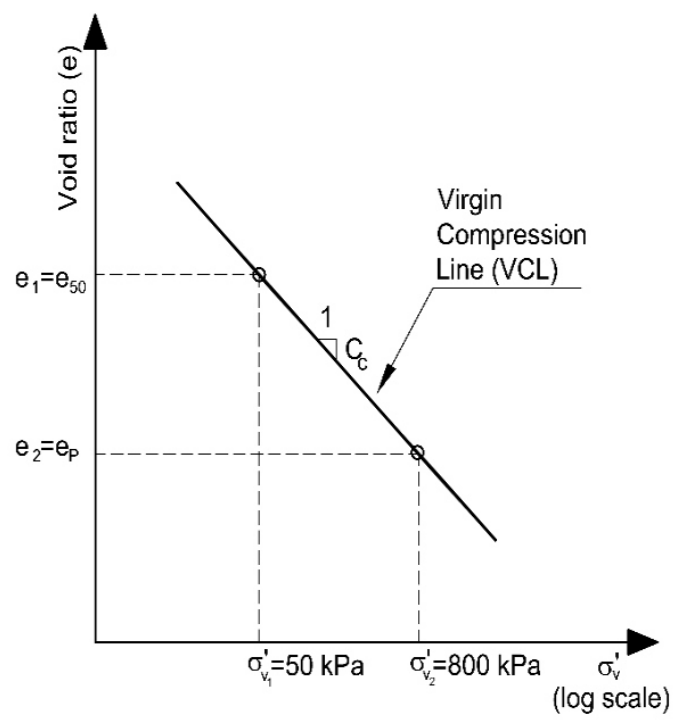

Fig. 4 Schematic graph of compression index calculation

As shown by both methods of normalisation, the relationship between void ratio invariants (void index $\left(I_{v}\right)$ and normalised void ratio $\left.\left(e / e_{L}\right)\right)$ and vertical stress is linear beyond $50 \mathrm{kPa}$ for the primary consolidation stage. Thus the void ratio at a vertical stress of $50 \mathrm{kPa}\left(e_{50}\right)$, has been chosen as the first point for calculating the slope of the virgin compression line. The second point chosen for slope calculation, based on Wroth and Wood, 1978 [10], is the void ratio at the plastic limit $\left(e_{P}\right)$ and its corresponding vertical stress of $800 \mathrm{kPa}$. By substituting the void ratios at a vertical stress of $50 \mathrm{kPa}$ and at the soil plastic limit ( $e_{50}$, and $\left.e_{P}\right)$, and their related vertical stresses $(50 \mathrm{kPa}$ and 800 $\mathrm{kPa}$ ) into Eq. 9, the compression index can be expressed in the form:

$C_{c}=\frac{e_{50}-e_{P}}{\log 800-\log 50}=0.830\left(e_{50}-e_{P}\right)$

By using the regression equation (Eq. 5), $e_{50}$ can be written using the void ratio at the liquid limit $e_{L}$, and the compression index can be written in the form:

$e_{50}=0.803 e_{L}$

$C_{c}=0.666 e_{L}-0.830 e_{P}$

Equation (12) suggests that the compressibility of a reconstituted clay is exclusively a function of the soil void ratio at its consistency limits. By replacing the void ratio with water content using the equation $w . G_{s}=S_{r} . e$ (where $w$ is the water content, $G_{s}$ is the specific gravity, and $S_{r}$ is the degree of saturation), Eq. 12 can be rewritten for consistency limits in a saturated condition $\left(S_{r}=\right.$ $100 \%$ ) by taking into account the average specific gravity for clays (2.6) in the form:

$$
C_{c}=0.0173 w_{L}-0.0216 w_{P}
$$

Ninety-two consolidation tests conducted under various mineralogy and soil conditions, and reported in the literature, were used as an independent database to estimate compression indexes using Eqs. 12 and 13. Results were then compared with values measured from consolidation tests, to validate the efficiency of the proposed relationships. The results of this comparison are presented in Fig. 5, which shows a reasonable agreement between the predicted values and the measurements reported in the literature. As discussed before, a unique relation exists between consolidation stress and plastic limit $[10,29]$. The result of this study also suggests that the assumption of the mean vertical consolidation stress at the plastic limit being 125 times that at the liquid limit is acceptable for the studied soils. Hence, it can be concluded that void ratios at 50 $\mathrm{kPa}$ and at the plastic limit can be employed for determining the compression index of reconstituted clays with acceptable accuracy.

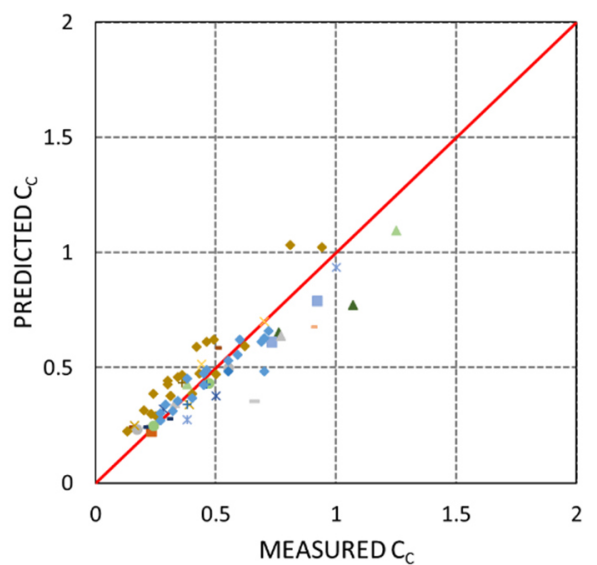

$$
\begin{aligned}
& \text { - ADAMS (2011) } \triangle M O H D \text { AMIN et al (1997) } \\
& \text { - BISCONTIN et al (2007) • COUTINHO and BELLO (2011) } \\
& \text { - COUTINHO et al (1998) } \quad \times \text { DEVIN and SANDFORD (1990) } \\
& \text { * GARGA et al (2006) - HONG et al (2010) } \\
& \text { - HOU et al (2011) } \quad \text { HUNT et al (2002) } \\
& \text { LEE et al (1990) + RASHWAN and KOUMOTO (2007) } \\
& \text { - SAMANG et al (2005) } \triangle \text { Simons et al } 2002 \\
& \times \text { TAN (2004) } \quad * \text { WALTON et al (1983) } \\
& \text { - WHITTLE (1974) + YAN and MA (2010) } \\
& \text { - SRIDHARAN and NAGARAJ (2000) - SHARMA and BORA (2015) }
\end{aligned}
$$

Fig. 5 Comparison between estimated and measured compression indexes (data extracted from Ref. [17, 21, 32-49]) 


\section{CONCLUSIONS}

Compression curves of normally consolidated reconstituted clays were normalised in the present paper using two methods of normalization, i.e. void ratio and void ratio at liquid limit $\left(e_{L}\right)$. Both methods show that the consolidation curves $(e-$ $\left.\log \sigma_{v}^{\prime}\right)$ are linear at stresses between $50-2000$ $\mathrm{kPa}$. It has also been shown that consolidation stress at the plastic limit can be assumed to be about 125 times greater (i.e. $800 \mathrm{kPa}$ ) than the correlated consolidation stress at the liquid limit based on the theoretical criteria proposed by Wroth and Wood, 1978 [10]. This unique point on the compression curve together with the point associated to a void ratio at $50 \mathrm{kPa}\left(e_{50}\right)$ were used to estimate the compression index of reconstituted soils. In fact, the compression index was found to be a unique function of the consistency limits (i.e. liquid limit $w_{L}$ and plastic limit $w_{P}$ ) for saturated reconstituted clays over the A-line in the plasticity chart. Based on these findings, an equation was proposed that uses consistency limits to estimate the compression index of reconstituted clays. The accuracy of the estimates was verified by comparison with a broad range of measured data from the literature. Findings indicate that the equation proposed in this study is suitable to predict the compression index of reconstituted clays above the A-line in the plasticity chart, with reasonable accuracy.

\section{REFERENCES}

[1] Skempton AW and Jones O, "Notes on the compressibility of clays". Quarterly Journal of the Geological Society, 1944, Vol. 100, No. 14, pp. 119-135.

[2] Terzaghi $\mathrm{K}$ and Peck RB, Soil mechanics in engineering practice. 2nd ed. 1967, New York: John Wiley \& Sons.

[3] Hough BK, Basic soils engineering. 1957, New York: Ronald Press.

[4] Das BM, Advanced soil mechanics. 2013: CRC Press.

[5] Arulrajah A, Nikraz H, and Bo MW. "In-situ testing of Singapore marine clay at Changi" Geotechnical \& Geological Engineering, 2005, Vol. 23, No. 2, pp. 111-130

[6] Bo MW, Victor C, Kai SW, and Arulrajah A "Laboratory validation of ultra-soft soil deformation model", Geotechnical and Geological Engineering, 2011, Vol. 29, No. 1, pp. 65-74.

[7] Cozzolino V, Statistical forecasting of compression index, in Proceedings of the 5th international conference on soil mechanics and foundation engineering. 1961, University Press of France: Paris.51-53.

[8] Nacci VA, Wang MC and Demars KR, Engineering behavior of calcareous soils, in Proceedings of Civil Engineering in the Oceans III, ASCE Specialty Conference, Newark, Del.
1975, American Society of Civil Engineer.380400.

[9] Azzouz AS, Krizek RJ and Corotis RB, "Regression analysis of soil compressibility". Soils Foundations, 1976, Vol. 16, No. 2, pp. 19-29.

[10] Wroth C and Wood D, "The correlation of index properties with some basic engineering properties of soils". Canadian Geotechnical Journal, 1978, Vol. 15, No. 2, pp. 137-145.

[11] Ogawa F, "Correlation of the mechanical and index properties of soils in harbor districts". Report of the Port and Harbor Research Institute, 1978, Vol. 17, No. 3, pp. 4-89 (in Japanese).

[12] Herrero O, "Universal compression index equation; closure". Journal of Geotechnical Engineering, ASCE, 1983, Vol. 109, No. 5, pp. 755-761.

[13] Nagaraj T and Murthy S, "Rationalization of skempton's compressibility equation". Geotechnique, 1983, Vol. 33, No. 4, pp. 433443.

[14]Nagaraj TS, Basavapatna R and Murthy S, "Prediction of the preconsolidation pressure and recompression index of soils". 1985, Vol., No., pp.

[15] Nagaraj T, Pandian N, Narasimha Raju P and Vishnu Bhushan T. Stress-state-timepermeability relationships for saturated soils. in Proceedings of the International Symposium on Compression and Consolidation of Clayey Soils. 1995.

[16] Bowles JE, Physical and geotechnical properties of soils. 1989, New York: McGrawHill Book.

[17] Sridharan A and Nagaraj H, "Compressibility behaviour of remoulded, fine-grained soils and correlation with index properties". Canadian Geotechnical Journal, 2000, Vol. 37, No. 3, pp. 712-722.

[18] Nagaraj T and Miura N, Soft clay behaviour analysis and assessment. 2001, Rotterdam, Netherlands: A. A. Balkema.

[19] Nath A and Dedalal S, "The role of plasticity index in predicting compression behaviour of clays". Electronic Journal of Geotechnical Engineering, 2004, Vol. 9, No., pp.

[20] Park J and Koumoto T, "New compression index equation". Journal of Geotechnical and Geoenvironmental Engineering, 2004, Vol. 130, No. 2, pp. 223-226.

[21]Hong ZS, Yin J and Cui YJ, "Compression behaviour of reconstituted soils at high initial water contents". Geotechnique, 2010, Vol. 60, No. 9, pp. 691-700.

[22] Habibbeygi F, Nikraz $\mathrm{H}$ and Chegenizadeh A, "Intrinsic compression characteristics of an expansive clay from Western Australia". International Journal of Geomate, 2017, Vol. 12, No. 29, pp. 140-147.

[23] Nagaraj T and Murthy S, "A critical reappraisal of compression index equations". Geotechnique, 1986, Vol. 36, No. 1, pp. 27-32.

[24] Burland JB, "On the compressibility and shear strength of natural clays". Geotechnique, 1990, Vol. 40, No. 3, pp. 329-378.

[25]Al Haj KMA and Standing JR, "Mechanical properties of two expansive clay soils from 
sudan". Géotechnique, 2015, Vol. 65, No. 4, pp. 258-273.

[26] Cerato $\mathrm{AB}$ and Lutenegger AJ, "Determining intrinsic compressibility of fine-grained soils". Journal of Geotechnical and Geoenvironmental Engineering, 2004, Vol. 130, No. 8, pp. 872877.

[27] Horpibulsuk S, Liu M, Zhuang Z and Hong Z$\mathrm{S}$, "Complete compression curves of reconstituted clays". International Journal of Geomechanics, 2016, Vol., No., pp. 06016005.

[28] Skempton A and Bishop A, Soils, chapter 10 of building materials- their elasticity and inelasticity, ed. M Reiner ,A G Ward. 1954, Amsterdam: North-Holland Publ. Co.

[29] Wood D and Wroth C. The correlation of some basic engineering properties of soils. in Proc. Conf. On Behaviour of Offshore Structures. 1976.

[30] Sharma B and Bora PK, "Plastic limit, liquid limit and undrained shear strength of soilreappraisal". Journal of Geotechnical and Geoenvironmental engineering, 2003, Vol. 129, No. 8, pp. 774-777.

[31] Sharma B and Bora P, "Determination of plastic limit of soils by cone penetration method". Indian Geotech J, 2004, Vol. 34, No. 4, pp. 297-312.

[32] Adams AL, Laboratory evaluation of the constant rate of strain and constant head techniques for measurement of the hydraulic conductivity of fine grained soils. 2011, Massachusetts Institute of Technology.

[33] Mohd Amin J et al, "Prediction and determination of undrained shear strength of soft clay at bukit raja". Pertanika Journal of Science \& Technology, 1997, Vol. 5, No. 1, pp. 111-126.

[34]Biscontin G, Cola S, Pestana JM and Simonini $\mathrm{P}$, "Unified compression model for venice lagoon natural silts". Journal of geotechnical and geoenvironmental engineering, 2007, Vol. 133, No. 8, pp. 932-942.

[35] Coutinho R and Bello M, "Analysis and control of the stability of embankments on soft soils juturnaíba and others experiences in brazil". Soils Rocks, 2011, Vol. 34, No. 4, pp. 331-351.

[36] Coutinho R, Oliveira $\mathrm{J}$ and Oliveira A, Geotechnical site characterization of recife soft clays. 1998, Balkema.1001-1006.

[37]Devin SC and Sandford TC, Stability of natural slopes in the presumpscot formation. 1990: Maine Geological Survey, Department of Conservation.

[38] Garga VK, Khan MA and Vanapalli SK, "Stress-path dependent behavior of a weathered clay crust". Geotechnical \& Geological Engineering, 2006, Vol. 24, No. 6, pp. 14811509.
[39]Hou Y, Wang J and Jeng D, "Threedimensional deformation behavior of an oversized excavation in shanghai clay". Geotechnical Engineering Journal of the SEAGS\&AGSSEA, 2011, Vol. 42, No. 3, pp. 22-29.

[40] Hunt CE, Pestana JM, Bray JD and Riemer M, "Effect of pile driving on static and dynamic properties of soft clay". Journal of geotechnical and geoenvironmental engineering, 2002, Vol. 128, No. 1, pp. 13-24.

[41]Lee HJ, Kayen RE and Mcarthur WG, "Consolidation, triaxial shear-strength, and index-property characteristics of organic-rich sediments from the peru margin". 1990.

[42] Rashwan $M$ and Koumoto $T$, "Undrained shear strength of ariake clay by electronic cone penetration testing". Lowland technology international: the officisl journal of the International Association of Lowland Technology (IALT)/Institute of Lowland Technology, Saga University, 2007, Vol. 9, No. 1, pp. 28-40.

[43] Samang L, Miura N and Sakai A, "Geotechnical properties of soft cohesive lowland soils deposited in saga airport highway, japan". Media Komunikasi Teknik Sipil, 2005, Vol. 13, No. 3, pp. 19-35.

[44] Simons NE, Menzies BK and Matthews MC, A short course in geotechnical site investigation. Vol. 5. 2002, London: Thomas Telford Ltd.

[45] Tan BB, Geotechnical characterization of sediments from hydrate ridge, cascadia continental margin. 2004, Massachusetts Institute of Technology.

[46] Walton W, Sangrey D and Miller S, "Geotechnical engineering characterization of hydraulically piston-cored deep ocean sediments". Initial Reports Of The Deep Sea Drilling Project, 1983, Vol. 72, No. Dec., pp. 537-549.

[47] Whittle JF, Consolidation behavior of an embankment on boston blue clay. 1974, Massachusetts Institute of Technology.

[48] Yan W and Ma Y, "Geotechnical characterization of macau marine deposits". Engineering Geology, 2010, Vol. 113, No. 1, pp. $62-69$.

[49] Sharma B and Bora PK, "A study on correlation between liquid limit, plastic limit and consolidation properties of soils". Indian Geotechnical Journal, 2015, Vol. 45, No. 2, pp. 225-230.

Copyright (C) Int. J. of GEOMATE. All rights reserved, including the making of copies unless permission is obtained from the copyright proprietors. 